\title{
Leptin as a Key between Obesity and Cardiovascular Disease
}

\author{
Ki-Woon Kang' ${ }^{1}$ Minho Ok², Seong-Kyu Lee ${ }^{3,4, *}$ \\ ${ }^{1}$ Division of Cardiology, Department of Internal Medicine, Eulji University School of Medicine, Daejeon; ${ }^{2}$ Department of Cardiovascular Pharmacology, Mokpo \\ National University, Mokpo; ${ }^{3}$ Division of Endocrinology, Department of Internal Medicine and ${ }^{4}$ Department of Biochemistry-Molecular Biology, Eulji University \\ School of Medicine, Daejeon, Korea
}

Obesity increases the risk of cardiovascular disease through various influencing factors. Leptin, which is predominantly secreted by adipose tissue, regulates satiety homeostasis and energy balance, and influences cardiovascular functions directly and indirectly. Leptin appears to play a role in heart protection in leptin-deficient and leptin-receptor-deficient rodent model experiments. Hyperleptinemia or leptin resistance in human obesity influences the vascular endothelium, cardiovascular structure and functions, inflammation, and sympathetic activity, which may lead to cardiovascular disease. Leptin is involved in many processes, including signal transduction, vascular endothelial function, and cardiac structural remodeling. However, the dual (positive and negative) regulator effect of leptin and its receptor on cardiovascular disease has not been completely understood. The protective role of leptin signaling in cardiovascular disease could be a promising target for cardiovascular disease prevention in obese patients.

Key words: Obesity, Leptin, Cardiovascular disease

\author{
Received November 19, 2020 \\ Reviewed December 3, 2020 \\ Accepted December 13, 2020 \\ ${ }^{*}$ Corresponding author \\ Seong-Kyu Lee \\ https://orcid.org/0000-0002-5999-7656 \\ Division of Endocrinology, Department \\ of Internal Medicine, Eulji University \\ Hospital and Department of \\ Biochemistry-Molecular Biology, \\ Eulji University School of Medicine, \\ 95 Dunsanseo-ro, Seo-gu, \\ Daejeon 35233, Korea \\ Tel: +82-42-259-1642 \\ Fax: +82-42-259-1539 \\ E-mail: Iskendo@hanmail.net
}

\section{INTRODUCTION}

Obesity increases the risk of cardiovascular disease through various influencing factors, ${ }^{1}$ such as hemodynamic changes, cardiac structure and cardiac function, inflammation, neurohumoral changes, and cellular remodeling (Fig. 1). ${ }^{2}$ The presence of large emerging adipocytes may be directly associated with production of leptin, angiotensin, proinflammatory cytokines, and reactive oxygen species. ${ }^{3}$ Moreover, progressive inflammation processes, oxidative stress, and hyperleptinemia in obesity is significantly correlated with developing cardiovascular diseases ${ }^{4}$ and hypertension (Fig. 1) ${ }^{5-7}$ Adipocyte-derived leptin exhibits pleiotropic effects. In obese people, hyperleptinemia is not sufficient to prevent energy balance dysreg- ulation, indicating that obese individuals are leptin resistant. $\mathrm{Al}$ though most obese cases are associated with hypothalamic leptin resistance, the peripheral effects of leptin signaling or leptin resistance in obesity are not fully elucidated. Moreover, the net effects of hyperleptinemia or leptin resistance on cardiovascular disease in obese people are complex and not completely understood. In this review, we discuss leptin as a key between obesity and cardiovascular disease (Fig. 1).

\section{RELATIONSHIP BETWEEN OBESITY AND CARDIOVASCULAR DISEASE}

Obesity can lead to cardiac structural remodeling, causing left

Copyright @ 2020 Korean Society for the Study of Obesity

(a) This is an Open Access article distributed under the terms of the Creative Commons Attribution Non-Commercial License (https://creativecommons.org/licenses/by-nc/4.o/) which permits unrestricted non-commercial use, distribution, and reproduction in any medium, provided the original work is properly cited. 


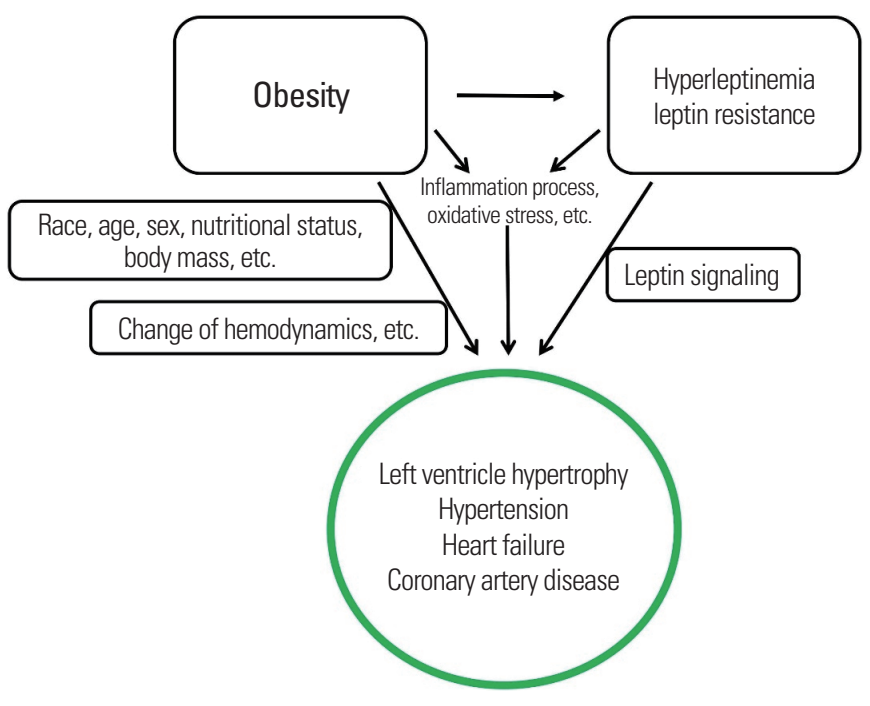

Figure 1. Overview of leptin as a key between obesity and cardiovascular disease. Obesity increases the risk of cardiovascular disease through the various factors: obesity-induced changes in hemodynamics, cardiac structure and cardiac function, inflammation, neurohumoral changes, and cellular remodeling, as well as hyperleptinemia and leptin resistance.

ventricular (LV) hypertrophy., ${ }^{8,9}$ When body mass index (BMI) increases by $1 \mathrm{~kg} / \mathrm{m}^{2}$, the risk of LV hypertrophy increases by $5.1 \%$, and when waist circumference increases by $1 \mathrm{~cm}$, the risk of LV hypertrophy increases by $2.6 \% .^{10}$ Furthermore, obesity is associated with vascular injuries, such as increased arterial stiffness, ${ }^{11}$ coronary artery calcification, ${ }^{12}$ increased carotid intima-media thickness, and higher incidence of carotid stenosis, ${ }^{13}$ all of which contributes to early vascular aging. ${ }^{14}$ Obesity has been recognized as an independent predictor of coronary artery disease $\mathrm{e}^{15,16}$ and carries an approximately two-fold higher risk of developing heart failure than a healthy weight. ${ }^{17,18}$ Studies have also shown correlations between stroke and BMI and waist-hip ratio, ${ }^{19,20}$ and population-based cohort studies have reported a $49 \%$ higher risk of arteriosclerosis in obese patients compared with non-obese patients. ${ }^{21}$

In contrast, among patients with heart failure, those who were overweight or obese $\left(\mathrm{BMI}>27.8 \mathrm{~kg} / \mathrm{m}^{2}\right)$ were clinically shown to have a higher survival rate. ${ }^{22} \mathrm{~A}$ follow-up analysis of 7,767 patients with chronic heart failure reported lower hazard ratios (HRs) in overweight or obese subjects (HR, $0.81 ; 95 \%$ confidence interval [CI], 0.72-0.92) than in normal-weight subjects (HR, 0.88; 95\% CI, 0.80-0.96). ${ }^{23}$ Similar results were observed in patients who experienced sudden cardiac arrest, wherein a higher BMI was associated with reduced mortality. ${ }^{24}$ Higher BMI was also associated with lower mortality in cases of coronary artery disease, heart failure, and diabetes. ${ }^{25}$ In general, obese patients have higher mortality; however, paradoxically, higher mortality is often observed in normal-weight patients compared with obese patients. ${ }^{26}$ This phenomenon, in which survival rates are higher among obese patients, in contrast to conventional expectations, is known as the "obesity paradox," and is most commonly observed in patients with coronary artery disease or heart failure. ${ }^{27}$

\section{THE ROLE OF LEPTIN}

Leptin is an important hormone involved in weight regulation and energy homeostasis. ${ }^{28-31}$ It is a $16-\mathrm{kD}$ a protein with 167 amino acids. ${ }^{32}$ Leptin is predominantly secreted by adipose tissue and is also secreted from other tissues, including the heart, via autocrine or paracrine effects. ${ }^{33,34}$ Leptin regulates appetite by controlling satiety signals to the central nervous system $(\mathrm{CNS})^{35}$ and it influences cardiovascular functions either directly or indirectly via secondary responses mediated by the vasculature (such as hypertension, endothelial function, atherosclerosis, and thrombopoiesis) or the $\mathrm{CNS}^{36}$

The ob (obesity) gene mutation and leptin receptor (LepR) mutants—ob/ob and $\mathrm{db} / \mathrm{db}$ mouse models, respectively—and fa/fa Zucker rat models were developed as obesity animal models. ${ }^{37}$ Heart failure is common to these animals, ${ }^{38}$ suggesting that leptin is linked to cardiovascular disease. In research using leptin- or LepRdeficient rodent models, leptin appears to play a role in heart protection.

Despite varying interpretations of the results of a meta-analysis of the effects of leptin on coronary artery disease, ${ }^{39}$ in the Multiethnic Study of Atherosclerosis study that included 1,910 patients with atherosclerosis only, leptin was not significantly correlated with cardiovascular disease. ${ }^{40}$ However, contradictory results have been reported in other studies that found a correlation between leptin and cardiovascular disease. In contrast, hyperleptinemia was found to be correlated with a positive prognosis for cardiovascular disease through coronary artery vasodilation, endothelial nitric oxide synthase (eNOS) activation, endothelial precursor cell activation, and reduced lipid accumulation. ${ }^{41}$ 


\section{LEPTIN RECEPTOR AND SIGNAL TRANSDUCTION}

LepR is simultaneously expressed in adipose, heart, muscle, lung, small intestine, and liver tissue, as well as the CNS, particularly the hypothalamus. LepR is a type-I cytokine receptor, from which six subtypes (LepRa to LepRf) are generated by selective splicing. ${ }^{42}$ Leptin signaling relies on LepR autophosphorylation, which triggers the pathways for Janus kinase (JAK), signal transducer and activator of transcription (STAT), insulin receptor substrate (IRS)/ phosphatidylinositol 3 kinase (PI3K), mitogen-activated protein kinase (MAPK), extracellular signal-regulated protein kinase (ERK), and 5 '-adenosine monophosphate-activated protein kinase (AMPK) (Fig. 2). Leptin may activate JAK2, IRS1, and ERK via LepRa; however, LepRb, with its long intracellular tail, appears to be the only subtype capable of mediating JAK/STAT signaling (Fig. 2). ${ }^{43,44}$

JAK/STAT signaling is triggered by JAK2 phosphorylation, followed by STAT3 phosphorylation and a conformational change due to binding. STAT3 forms a dimer that enters the nucleus to regulate the expression of genes governing food ingestion. ${ }^{44}$ Such signaling pathways include negative feedback - suppressor of cytokine signaling 3 (SOC3) negatively regulates the JAK/STAT pathway by interfering with the phosphorylation of the tyrosine residue of LepR (Fig. 2). Moreover, STAT3 repressor hinders STAT3 binding to DNA, and protein tyrosine phosphatase- $1 \mathrm{~B}$ interrupts phosphorylation of JAK2 and STAT3 and negatively regulates leptin signaling (Fig. 2). ${ }^{44}$

Leptin also mediates MAPK and ERK signaling (Fig. 2). Binding of leptin results in $\mathrm{SH} 2$-containing protein tyrosine phosphatase 2 (SHP2) phosphorylation, and growth factor receptor-bound protein 2 (Grb2) activates ERK. Moreover, irrespective of LepRb phosphorylation, JAK2 activates downstream signaling via Grb2 and $\mathrm{SHP} 2 .{ }^{45} \mathrm{PI} 3 \mathrm{~K}$ is a dimer and has a component that regulates signaling by acting as a catalyst. LepR activation facilitates the interaction and complex formation of JAK2/IRS1 to downregulate targets such as protein kinase $\mathrm{B}$ (Akt). ${ }^{44}$

Elevated leptin levels are generally observed in obese people, which led to a hypothesis that elevated leptin levels may be linked

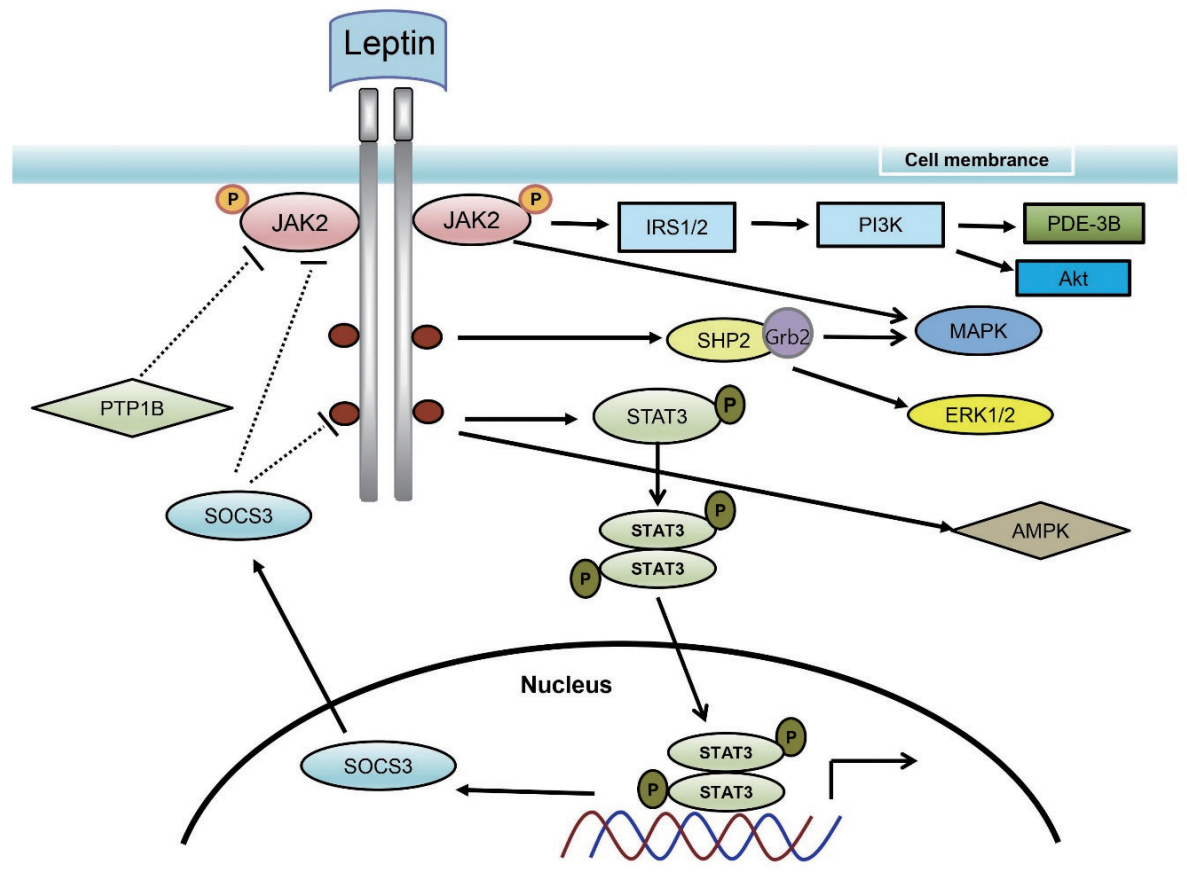

Figure 2. Signal transduction process of leptin. Leptin signaling relies on leptin receptor autophosphorylation, which triggers the JAK2, STAT3, IRS/PI3K, MAPK, ERK, and AMPK pathways. JAK, Janus kinase; IRS, insulin receptor substrate; PI3K, phosphatidylinositol 3 kinase; PDE, phosphodiesterase; Akt, protein kinase B; SHP2, SH2-containing protein tyrosine phosphatase 2; Grb2, growth factor receptor-bound protein 2; MAPK, mitogen-activated protein kinase; PTP, protein tyrosine phosphatase; STAT, signal transducer and activator of transcription; ERK, extracellular signal-regulated protein kinase; SOCS3, suppressor of cytokine signaling 3; AMPK, 5'-adenosine monophosphate-activated protein kinase. 
to leptin resistance. ${ }^{35,46}$ If leptin resistance causes changes in leptin signaling (such as changes in LepR tyrosine residues or the leptinbinding site), additional studies are required to understand this phenomena. Whether leptin resistance is just inhibition of leptin signaling that affects the heart or whether other adipokines also affect the heart needs to be investigated.

\section{RELATIONSHIP BETWEEN LEPTIN AND CARDIAC HYPERTROPHY}

The increased blood volume in obese patients increases cardiac output and stimulates biomechanical stress and structural remodeling that may result in cardiac hypertrophy. ${ }^{8,9,47} \mathrm{~A}$ correlation between plasma leptin levels and cardiac hypertrophy has been clinically demonstrated. ${ }^{48}$ Numerous studies observed that leptin directly induces cardiac hypertrophy in humans and mice. ${ }^{33,49-55}$ Leptin induces cardiac hypertrophy through diverse pathways such as the mammalian target of rapamycin signaling, ${ }^{56}$ calcineurin activation and nuclear factor of activated $T$ cells transportation into the nucleus, ${ }^{57}$ peroxisome proliferator-activated receptor- $\alpha$ activation, ${ }^{58}$ MAPK 14 (p38) activation and transportation into the nucleus, ${ }^{50,52}$ activation of Rho and actin dynamics, ${ }^{49}$ and increases in intracellular reactive oxygen species. ${ }^{51,59}$

LV hypertrophy is often observed in ob/ob and $\mathrm{db} / \mathrm{db}$ mice morbidly predisposed to obesity ${ }^{60-63}$ However, when adequate leptin levels are provided, the LV returns to its normal thickness, regardless of the mouse's weight. ${ }^{62}$ Hyperleptinemia is observed in the heart in a diet-induced obese mouse model, and LepR constantly responds to elevated plasma or cardiac leptin levels. This appears to provide protection against cardiac hypertrophy via STAT3 activation and its downstream pathways and by affecting p38 and p42/44 MAPK as well as Akt, in comparison to LepR mutants or $\mathrm{db} / \mathrm{db}$ mouse models. ${ }^{60}$

Despite the studies that conclude that leptin causes cardiac hypertrophy, research by Leifheit-Nestler et al. ${ }^{60}$ showed protective effects of leptin on cardiac hypertrophy. They investigated LepR in relation to STAT3, but other effects of leptin also require investigation. Influential factors that require consideration are the mouse model species, leptin resistance in obesity, age, sex, and patient nutritional status. Without this knowledge, it is unclear whether obe- sity-induced cardiac hypertrophy is the result of leptin-driven cardiac hypertrophy or resistance to the cardio-protective effects of leptin. $^{60}$

\section{RELATIONSHIP BETWEEN LEPTIN AND CARDIAC FUNCTION}

$\mathrm{Ca}^{2+}$ influx into the heart acts as a multifunctional signal that causes the heart muscles to contract, controls the period of action potential maintenance, and regulates gene expression. ${ }^{64}$ During the period of excitation-contraction coupling in the heart, $\beta$-adrenergic signals activate the $\mathrm{Na}^{+} / \mathrm{Ca}^{2+}$ exchange channels via protein kinase A (PKA) signaling while causing depolarization of the sarcolemma. ${ }^{65}$ Depolarization of the sarcolemma leads to the opening of high-voltage-activated L-type calcium channels and allows $\mathrm{Ca}^{2+}$ entry into the cytoplasm, which, in turn, causes $\mathrm{Ca}^{2+}$ release through ryanodine receptor channels into the sarcoplasmic reticulum (SR) for muscle contraction initiation. ${ }^{65}$ Sarcoplasmic/endoplasmic reticulum calcium ATPase 2 (SERCA2) and phospholamban (PLN) play crucial roles in transporting $\mathrm{Ca}^{2+}$ from myocytes and the cytoplasm. ${ }^{66}$ Abnormal $\mathrm{Ca}^{2+}$ circulation in the SR characterizes cardiac diseases such as heart failure and arteriosclerosis and contributes to the pathophysiology of disease progression. ${ }^{66,67}$

Decreased activation of SERCA2 and $\mathrm{Na}^{+} / \mathrm{Ca}^{2+}$ exchange channels is observed in leptin-deficient mice, ${ }^{68}$ whereas leptin treatment to the myocytes of ob/ob mice improved $\beta$-adrenergic signaling and increased Gs $\alpha$ expression, PKA activation, and PLN phosphorylation. ${ }^{69}$ These results suggest a definite correlation between leptin and cardiac function. ${ }^{70,71}$ Moreover, leptin treatment to cardiomyocytes of adult mice also resulted in suppressed contraction via different pathways (e.g., endothelin-1 receptor- nicotinamide adenine dinucleotide phosphate $\mathrm{H}$ oxidase pathway, ${ }^{70,71}$ nitric oxide, ${ }^{72}$ JAK/STAT pathway, ${ }^{73}$ interleukin-1 $\beta$ signaling, ${ }^{74}$ autophagy induction $^{75}$ ).

\section{RELATIONSHIP BETWEEN LEPTIN AND CARDIOMYOCYTE APOPTOSIS}

Apoptosis, through strict regulation of specific signaling steps, is the main cause of cell loss in the heart. ${ }^{76}$ Cardiomyocyte apoptosis 
plays a key role in the progression of heart failure and is especially important for compensatory remodeling in heart failure. ${ }^{77}$ Cells undergoing apoptosis experience structural changes including shrinking, plasma membrane blebbing, nuclear condensation, and DNA and nuclear fragmentation. ${ }^{78}$ Once cells become apoptotic bodies, they are removed by macrophages. ${ }^{76}$ Apoptosis is mediated via two different pathways: the first is the extrinsic or death receptor pathway activated by death-domain-containing receptors in the plasma membrane, and the second is the intrinsic or mitochondrial pathway activated by intracellular stress from growth factors, low oxygen concentration, oxidative stress, and DNA damage. ${ }^{76}$ Apoptotic signals instantly activate caspases and disable the mitochondria, leading to cell death.

Zucker rats showed increased apoptosis via both the extrinsic and intrinsic pathways. ${ }^{79,80} \mathrm{In} \mathrm{ob} / \mathrm{ob}$ and $\mathrm{db} / \mathrm{db}$ mice and fa/fa rats, impaired leptin signaling caused a rise in triglyceride levels, which led to lipid accumulation and induction of cardiomyocyte apoptosis. However, when normal leptin levels were reached, excessive lipid accumulation was prevented and cardiac function was restored, ${ }^{61,81}$ indicating that increased apoptosis in obese mouse models was not due to aging or cellular damage but directly associated with impaired leptin signaling. Moreover, in knock-out mice models with cardiomyocyte-specific deletions of LepR, impaired leptin signaling directly led to increased cardiac hypertrophy, apoptosis, deterioration of cardiac structure and function, and impairment of energy, glucose, and fatty acid metabolism, which further accelerated heart damage due to myocardial infarction. ${ }^{82}$

Apoptosis can be induced by a mechanism where the opening of the mitochondrial permeability transition pore ( $\mathrm{mPTP}$ ) releases cytochrome $\mathrm{C}$ into the cytoplasm. ${ }^{83}$ Leptin prevents the opening of mPTP in mouse cardiomyocytes ${ }^{8486}$ and can also protect cardiomyocytes from apoptosis induced by $\mathrm{H}_{2} \mathrm{O}_{2}$ or hypoxia-reoxygenation conditions. ${ }^{87,88}$

Tumor necrosis factor (TNF)- $\alpha$ at high concentrations binds to TNFR-1 to cause cardiomyocyte apoptosis, leading to various cardiovascular diseases. ${ }^{89-91}$ Leptin treatment in mouse cardiomyocytes interfered with the caspase- 3 fragmentation and the intrinsic mitochondrial pathway, thereby preventing TNF- $\alpha$-induced apoptosis. ${ }^{87}$ Despite reports that leptin treatment causes apoptosis, ${ }^{92,93}$ it seems clear that leptin plays a protective role against apoptosis pro- gression under stressful physiological conditions. Furthermore, it should be noted that leptin treatment could prevent apoptosis by blocking TNF- $\alpha$-induced pathways (e.g., caspase-3 fragmentation, poly adenosine diphosphate ribose polymerase segmentation, p38 MAPK/nuclear factor kappa B phosphorylation, Bax transport). ${ }^{94}$ If these downstream pathways could be regulated by leptin, cardiomyocyte apoptosis could be controlled and cardiovascular disease progression could be halted.

\section{RELATIONSHIP BETWEEN LEPTIN AND ENDOTHELIAL VASCULAR FUNCTION}

Leptin was initially thought to stimulate the sympathetic nerve, ${ }^{95}$ raising blood pressure. However, leptin was not found to exert significant effects on blood pressure on its own. ${ }^{96-98} \mathrm{~A}$ number of experiments demonstrated that leptin is involved in endothelium-dependent vasodilation via nitric oxide, ${ }^{99-101}$ which was further observed in leptin-deficient ob/ob mice, where arterial vessel contraction mediated by noradrenaline or phenylephrine increased while vasodilation by acetylcholine weakened. These anomalies disappeared when leptin levels were restored. ${ }^{102}$

Leptin induces Akt phosphorylation ${ }^{103}$ and phosphorylated Akt then induces phosphorylation of the eNOS serine residue, which heightens its activity. eNOS produces nitric oxide, which activates soluble guanylyl cyclase. This stimulates cyclic guanosine monophosphate synthesis in smooth muscle cells, leading to vasodilation. Although eNOS can also be activated by insulin, leptin is capable of activating the PI3K-independent Akt/eNOS pathway. ${ }^{104}$ Leptin also seems to mediate vasodilation via endothelium-derived hyperpolarizing factor (EDHF). ${ }^{105}$

Leptin resistance is observed in obesity and metabolic syndrome, ${ }^{35,46}$ where the effect of leptin on nitric-oxide-induced vasodilation becomes less significant. During the early stages, a compensatory response may originate from EDHF, but even this becomes inadequate as leptin resistance duration increases. Consequently, lack of dilation and continued stimulation of the sympathetic nerve causes hypertension and atherosclerosis. ${ }^{106}$ Nonetheless, it is anticipated that elucidating the signaling pathway between leptin and endothelial cells and uncovering the mechanism of the role of leptin resistance in blood vessels would lead to a reliable 
treatment strategy for obesity-associated vascular diseases.

Leptin causes atherosclerosis through diverse mechanisms including the entry of monocytes into blood vessels, transformation of macrophages into foam cells, proliferation of vascular smooth muscle cells, and secretion of atherosclerotic cytokines, which suggests that leptin indirectly causes atherosclerosis. ${ }^{107}$ A recent study reported a protective role for leptin against atherosclerosis in a concentration-dependent manner in low-density lipoprotein receptor $^{-/-} \mathrm{ob} / \mathrm{ob}$ mice. ${ }^{108}$ Leptin exerts protective effects by reducing liver cholesterol or lowering its synthase mRNA expression. ${ }^{109-111}$ Furthermore, adiposity and related inflammation are independent prognostic factors alongside fibrosis in the progression and detection of atherosclerosis, and leptin relieves local inflammation in the liver by down-regulating inflammatory cytokines such as monocyte chemoattractant protein- 1, TNF- $\alpha$, and fibrosis marker transforming growth factor- $\beta{ }^{112,113}$ Based on these findings, it seems important to elucidate the mode of liver cholesterol metabolism under physiological conditions and in leptin deficiency for ameliorating atherosclerosis progression. Moreover, the facilitated release of nitric oxide by leptin and the association of nitric oxide and sympathetic nerve activation may be another mechanism that prevents atherosclerosis. ${ }^{114}$ Such results, however, do not contradict the role of leptin in causing atherosclerosis when its levels are higher than normal. As previously mentioned, leptin causes atherosclerosis indirectly. Leptin and its receptors are expressed in atherosclerotic plaques in mice as well as humans, ${ }^{115,116}$ and high levels of leptin are known to elevate cardiovascular risk factors such as plasma fibrinogens, which suggest that high levels of leptin may contribute to atherosclerosis. $^{117}$

\section{RELATIONSHIP BETWEEN LEPTIN AND SYMPATHETIC STIMULATION}

Sympathetic nerve activation is observed in obese patients ${ }^{118}$ as well as in animal models of obesity. ${ }^{119}$ In several tissue types, leptin seems to promote sympathetic nerve activation involved in cardiovascular regulation, which raises arterial pressure. ${ }^{120}$ Furthermore, although leptin, when administered, was ineffective in regulating energy homeostasis in obesity, its influence on cardiovascular sympathetic nerve hyperactivity and blood pressure was maintained. ${ }^{121}$
This indicates a selective influence of leptin resistance. This is supported by the finding that blood pressure decreased when sympathetic nerve activity was inhibited and central leptin signaling was blocked in obese rabbits. ${ }^{122}$

It is broadly agreed that hypertension is caused by sympathetic nerve activation that affects peripheral resistance or blood flow in the kidneys, and that leptin levels are elevated in obese individuals. ${ }^{123}$ However, because leptin treatment in healthy individuals does not affect hypertension, it is worth considering whether hypertension is caused by elevated leptin levels or leptin signaling deficiency due to leptin resistance or by the burden of cardiac hypertrophy due to obesity. Additionally, demographic factors besides leptin (e.g., race, age, sex) should be considered. If it is the elevated leptin or leptin signaling deficiency due to leptin resistance in obesity that causes hypertension, then the condition might be controlled by regulating the downstream pathways (STATs, PI3K, ERK1/2, SOC3, etc.) (Fig. 2). ${ }^{124}$

\section{CONCLUSION}

Leptin exerts its influence on the cardiovascular system in a number of ways. Obesity and leptin cannot be simply said to have either a negative or a protective role in cardiovascular disease. Nevertheless, a number of studies have shown that leptin has protective effects on cardiovascular disease. Future investigations should confirm whether elevated leptin levels themselves are responsible for cardiovascular disease or whether leptin resistance is responsible for cardiovascular disease in human obesity. If leptin plays different roles under different conditions, other factors including race, age, sex, nutritional status, BMI, and leptin resistance should be considered. The protective role of leptin signaling in cardiovascular disease could be a promising target to prevent cardiovascular disease in obese patients.

\section{CONFLICTS OF INTEREST}

The authors declare no conflict of interest.

\section{AUTHOR CONTRIBUTIONS}

Study concept and design: KWK and SKL; analysis and interpre- 
tation of data: KWK and MO; drafting of the manuscript: KWK and MO; critical revision of the manuscript: SKL; and study supervision: SKL.

\section{REFERENCES}

1. Sharma AM. Adipose tissue: a mediator of cardiovascular risk. Int J Obes Relat Metab Disord 2002;26 Suppl 4:S5-7.

2. Lavie CJ, Milani RV, Ventura HO. Obesity and cardiovascular disease: risk factor, paradox, and impact of weight loss. J Am Coll Cardiol 2009;53:1925-32.

3. Pausova Z. From big fat cells to high blood pressure: a pathway to obesity-associated hypertension. Curr Opin Nephrol Hypertens 2006;15:173-8.

4. Ridker PM. High-sensitivity C-reactive protein: potential adjunct for global risk assessment in the primary prevention of cardiovascular disease. Circulation 2001;103:1813-8.

5. Harrison DG, Guzik TJ, Lob HE, Madhur MS, Marvar PJ, Thabet SR, et al. Inflammation, immunity, and hypertension. Hypertension 2011;57:132-40.

6. Mathieu P, Lemieux I, Després JP. Obesity, inflammation, and cardiovascular risk. Clin Pharmacol Ther 2010;87:407-16.

7. Pou KM, Massaro JM, Hoffmann U, Vasan RS, MaurovichHorvat P, Larson MG, et al. Visceral and subcutaneous adipose tissue volumes are cross-sectionally related to markers of inflammation and oxidative stress: the Framingham Heart Study. Circulation 2007;116:1234-41.

8. Kuch B, Muscholl M, Luchner A, Döring A, Riegger GA, Schunkert $\mathrm{H}$, et al. Gender specific differences in left ventricular adaptation to obesity and hypertension. J Hum Hypertens 1998;12:685-91.

9. Kuperstein R, Hanly P, Niroumand M, Sasson Z. The importance of age and obesity on the relation between diabetes and left ventricular mass. J Am Coll Cardiol 2001;37: 1957-62.

10. Bombelli M, Facchetti R, Sega R, Carugo S, Fodri D, Brambilla $\mathrm{G}$, et al. Impact of body mass index and waist circumference on the long-term risk of diabetes mellitus, hypertension, and cardiac organ damage. Hypertension 2011;58: 1029-35.
11. Zebekakis PE, Nawrot T, Thijs L, Balkestein EJ, van der Heijden-Spek J, Van Bortel LM, et al. Obesity is associated with increased arterial stiffness from adolescence until old age. J Hypertens 2005;23:1839-46.

12. Cassidy AE, Bielak LF, Zhou Y, Sheedy PF 2nd, Turner ST, Breen JF, et al. Progression of subclinical coronary atherosclerosis: does obesity make a difference? Circulation 2005; 111:1877-82.

13. Ingelsson E, Sullivan LM, Fox CS, Murabito JM, Benjamin EJ, Polak JF, et al. Burden and prognostic importance of subclinical cardiovascular disease in overweight and obese individuals. Circulation 2007;116:375-84.

14. Nilsson PM, Lurbe E, Laurent S. The early life origins of vascular ageing and cardiovascular risk: the EVA syndrome. J Hypertens 2008;26:1049-57.

15. Hubert HB, Feinleib M, McNamara PM, Castelli WP. Obesity as an independent risk factor for cardiovascular disease: a 26-year follow-up of participants in the Framingham Heart Study. Circulation 1983;67:968-77.

16. Manson JE, Colditz GA, Stampfer MJ, Willett WC, Rosner B, Monson RR, et al. A prospective study of obesity and risk of coronary heart disease in women. N Engl J Med 1990;322: 882-9.

17. Kenchaiah S, Evans JC, Levy D, Wilson PW, Benjamin EJ, Larson MG, et al. Obesity and the risk of heart failure. N Engl J Med 2002;347:305-13.

18. Lee DS, Massaro JM, Wang TJ, Kannel WB, Benjamin EJ, Kenchaiah S, et al. Antecedent blood pressure, body mass index, and the risk of incident heart failure in later life. Hypertension 2007;50:869-76.

19. Rexrode KM, Hennekens CH, Willett WC, Colditz GA, Stampfer MJ, Rich-Edwards JW, et al. A prospective study of body mass index, weight change, and risk of stroke in women. JAMA 1997;277:1539-45.

20. Walker SP, Rimm EB, Ascherio A, Kawachi I, Stampfer MJ, Willett WC. Body size and fat distribution as predictors of stroke among US men. Am J Epidemiol 1996;144:1143-50.

21. Wanahita N, Messerli FH, Bangalore S, Gami AS, Somers VK, Steinberg JS. Atrial fibrillation and obesity--results of a meta-analysis. Am Heart J 2008;155:310-5. 
22. Horwich TB, Fonarow GC, Hamilton MA, MacLellan WR, Woo MA, Tillisch JH. The relationship between obesity and mortality in patients with heart failure. J Am Coll Cardiol 2001;38:789-95.

23. Bozkurt B, Deswal A. Obesity as a prognostic factor in chronic symptomatic heart failure. Am Heart J 2005;150:1233-9.

24. Matinrazm S, Ladejobi A, Pasupula DK, Javed A, Durrani A, Ahmad S, et al. Effect of body mass index on survival after sudden cardiac arrest. Clin Cardiol 2018;41:46-50.

25. Goyal A, Nimmakayala KR, Zonszein J. Is there a paradox in obesity? Cardiol Rev 2014;22:163-70.

26. Braun N, Gomes F, Schütz P. "The obesity paradox" in disease--is the protective effect of obesity true? Swiss Med Wkly 2015; 145:w14265.

27. Wannamethee SG, Shaper AG, Whincup PH, Lennon L, Papacosta O, Sattar N. The obesity paradox in men with coronary heart disease and heart failure: the role of muscle mass and leptin. Int J Cardiol 2014;171:49-55.

28. Friedman JM. Leptin, leptin receptors, and the control of body weight. Nutr Rev 1998;56(2 Pt 2):s38-46.

29. Park HK, Ahima RS. Leptin signaling. F1000Prime Rep 2014; 6:73.

30. Pelleymounter MA, Cullen MJ, Baker MB, Hecht R, Winters $\mathrm{D}$, Boone $\mathrm{T}$, et al. Effects of the obese gene product on body weight regulation in ob/ob mice. Science 1995;269: 540-3.

31. Rosenbaum M, Leibel RL. 20 years of leptin: role of leptin in energy homeostasis in humans. J Endocrinol 2014;223: T83-96.

32. Faggioni R, Feingold KR, Grunfeld C. Leptin regulation of the immune response and the immunodeficiency of malnutrition. FASEB J 2001;15:2565-71.

33. Rajapurohitam V, Javadov S, Purdham DM, Kirshenbaum LA, Karmazyn M. An autocrine role for leptin in mediating the cardiomyocyte hypertrophic effects of angiotensin II and endothelin-1. J Mol Cell Cardiol 2006;41:265-74.

34. Purdham DM, Zou MX, Rajapurohitam V, Karmazyn M. Rat heart is a site of leptin production and action. Am J Physiol Heart Circ Physiol 2004;287:H2877-84.

35. Ahima RS, Flier JS. Leptin. Annu Rev Physiol 2000;62:
413-37.

36. Koh KK, Park SM, Quon MJ. Leptin and cardiovascular disease: response to therapeutic interventions. Circulation 2008; 117:3238-49.

37. Lutz TA, Woods SC. Overview of animal models of obesity. Curr Protoc Pharmacol 2012; Chapter 5:Unit5.61.

38. Ren J, Dong F, Cai GJ, Zhao P, Nunn JM, Wold LE, et al. Interaction between age and obesity on cardiomyocyte contractile function: role of leptin and stress signaling. PLoS One 2010;5:e10085.

39. Sweeney G. Cardiovascular effects of leptin. Nat Rev Cardiol 2010;7:22-9.

40. Martin SS, Blaha MJ, Muse ED, Qasim AN, Reilly MP, Blumenthal RS, et al. Leptin and incident cardiovascular disease: the Multi-ethnic Study of Atherosclerosis (MESA). Atherosclerosis 2015;239:67-72.

41. Wolk R, Bertolet M, Singh P, Brooks MM, Pratley RE, Frye $\mathrm{RL}$, et al. Prognostic value of adipokines in predicting cardiovascular outcome: explaining the obesity paradox. Mayo Clin Proc 2016;91:858-66.

42. Mercer JG, Hoggard N, Williams LM, Lawrence CB, Hannah LT, Trayhurn P. Localization of leptin receptor mRNA and the long form splice variant ( $\mathrm{Ob}-\mathrm{Rb})$ in mouse hypothalamus and adjacent brain regions by in situ hybridization. FEBS Lett 1996;387:113-6.

43. Tartaglia LA, Dembski M, Weng X, Deng N, Culpepper J, Devos $\mathrm{R}$, et al. Identification and expression cloning of a leptin receptor, OB-R. Cell 1995;83:1263-71.

44. Wada N, Hirako S, Takenoya F, Kageyama H, Okabe M, Shioda S. Leptin and its receptors. J Chem Neuroanat 2014;6162:191-9.

45. Myers MG Jr. Leptin receptor signaling and the regulation of mammalian physiology. Recent Prog Horm Res 2004;59: 287-304.

46. Martin SS, Qasim A, Reilly MP. Leptin resistance: a possible interface of inflammation and metabolism in obesity-related cardiovascular disease. J Am Coll Cardiol 2008;52:1201-10.

47. Carreño JE, Apablaza F, Ocaranza MP, Jalil JE. Cardiac hypertrophy: molecular and cellular events. Rev Esp Cardiol 2006;59:473-86. 
48. Paolisso G, Tagliamonte MR, Galderisi M, Zito GA, Petrocelli A, Carella C, et al. Plasma leptin level is associated with myocardial wall thickness in hypertensive insulin-resistant men. Hypertension 1999;34:1047-52.

49. Zeidan A, Javadov S, Karmazyn M. Essential role of Rho/ ROCK-dependent processes and actin dynamics in mediating leptin-induced hypertrophy in rat neonatal ventricular myocytes. Cardiovasc Res 2006;72:101-11.

50. Zeidan A, Javadov S, Chakrabarti S, Karmazyn M. Leptininduced cardiomyocyte hypertrophy involves selective caveolae and RhoA/ROCK-dependent p38 MAPK translocation to nuclei. Cardiovasc Res 2008;77:64-72.

51. Xu FP, Chen MS, Wang YZ, Yi Q Lin SB, Chen AF, et al. Leptin induces hypertrophy via endothelin-1-reactive oxygen species pathway in cultured neonatal rat cardiomyocytes. Circulation 2004;110:1269-75.

52. Rajapurohitam V, Gan XT, Kirshenbaum LA, Karmazyn M. The obesity-associated peptide leptin induces hypertrophy in neonatal rat ventricular myocytes. Circ Res 2003;93: 277-9.

53. Majumdar P, Chen S, George B, Sen S, Karmazyn M, Chakrabarti S. Leptin and endothelin-1 mediated increased extracellular matrix protein production and cardiomyocyte hypertrophy in diabetic heart disease. Diabetes Metab Res Rev 2009;25:452-63.

54. Madani S, De Girolamo S, Muñoz DM, Li RK, Sweeney G. Direct effects of leptin on size and extracellular matrix components of human pediatric ventricular myocytes. Cardiovasc Res 2006;69:716-25.

55. Abe Y, Ono K, Kawamura T, Wada H, Kita T, Shimatsu A, et al. Leptin induces elongation of cardiac myocytes and causes eccentric left ventricular dilatation with compensation. Am J Physiol Heart Circ Physiol 2007;292:H2387-96.

56. Zeidan A, Hunter JC, Javadov S, Karmazyn M. mTOR mediates RhoA-dependent leptin-induced cardiomyocyte hypertrophy. Mol Cell Biochem 2011;352:99-108.

57. Rajapurohitam V, Izaddoustdar F, Martinez-Abundis E, Karmazyn M. Leptin-induced cardiomyocyte hypertrophy reveals both calcium-dependent and calcium-independent/RhoAdependent calcineurin activation and NFAT nuclear translo- cation. Cell Signal 2012;24:2283-90.

58. Hou N, Luo MS, Liu SM, Zhang HN, Xiao Q, Sun P, et al. Leptin induces hypertrophy through activating the peroxisome proliferator-activated receptor $\alpha$ pathway in cultured neonatal rat cardiomyocytes. Clin Exp Pharmacol Physiol 2010;37:1087-95.

59. Hu TP, Xu FP, Li YJ, Luo JD. Simvastatin inhibits leptin-induced hypertrophy in cultured neonatal rat cardiomyocytes. Acta Pharmacol Sin 2006;27:419-22.

60. Leifheit-Nestler M, Wagner NM, Gogiraju R, Didié M, Konstantinides S, Hasenfuss G, et al. Importance of leptin signaling and signal transducer and activator of transcription-3 activation in mediating the cardiac hypertrophy associated with obesity. J Transl Med 2013;11:170.

61. Barouch LA, Gao D, Chen L, Miller KL, Xu W, Phan AC, et al. Cardiac myocyte apoptosis is associated with increased DNA damage and decreased survival in murine models of obesity. Circ Res 2006;98:119-24.

62. Barouch LA, Berkowitz DE, Harrison RW, O’Donnell CP, Hare JM. Disruption of leptin signaling contributes to cardiac hypertrophy independently of body weight in mice. Circulation 2003;108:754-9.

63. Raju SV, Zheng M, Schuleri KH, Phan AC, Bedja D, Saraiva $\mathrm{RM}$, et al. Activation of the cardiac ciliary neurotrophic factor receptor reverses left ventricular hypertrophy in leptin-deficient and leptin-resistant obesity. Proc Natl Acad Sci USA 2006;103:4222-7.

64. Shaw RM, Colecraft HM. L-type calcium channel targeting and local signalling in cardiac myocytes. Cardiovasc Res 2013;98:177-86.

65. Bers DM, Shannon TR. Calcium movements inside the sarcoplasmic reticulum of cardiac myocytes. J Mol Cell Cardiol 2013;58:59-66.

66. Kho C, Lee A, Hajjar RJ. Altered sarcoplasmic reticulum calcium cycling: targets for heart failure therapy. Nat Rev Cardiol 2012;9:717-33.

67. Ibrahim M, Gorelik J, Yacoub MH, Terracciano CM. The structure and function of cardiac t-tubules in health and disease. Proc Biol Sci 2011;278:2714-23.

68. Dong F, Yang X, Sreejayan N, Ren J. Chromium (D-phenyl- 
alanine)3 improves obesity-induced cardiac contractile defect in ob/ob mice. Obesity (Silver Spring) 2007;15:2699711.

69. Minhas KM, Khan SA, Raju SV, Phan AC, Gonzalez DR, Skaf MW, et al. Leptin repletion restores depressed $\beta$-adrenergic contractility in ob/ob mice independently of cardiac hypertrophy. J Physiol 2005;565(Pt 2):463-74.

70. Dong F, Zhang X, Yang X, Esberg LB, Yang H, Zhang Z, et al. Impaired cardiac contractile function in ventricular myocytes from leptin-deficient ob/ob obese mice. J Endocrinol 2006; 188:25-36.

71. Dong F, Zhang X, Ren J. Leptin regulates cardiomyocyte contractile function through endothelin-1 receptor-NADPH oxidase pathway. Hypertension 2006;47:222-9.

72. Nickola MW, Wold LE, Colligan PB, Wang GJ, Samson WK, Ren J. Leptin attenuates cardiac contraction in rat ventricular myocytes: role of NO. Hypertension 2000;36:501-5.

73. Wold LE, Relling DP, Duan J, Norby FL, Ren J. Abrogated leptin-induced cardiac contractile response in ventricular myocytes under spontaneous hypertension: role of Jak/ STAT pathway. Hypertension 2002;39:69-74.

74. Radin MJ, Holycross BJ, McCune SA, Altschuld RA. Crosstalk between lepti and interleukin- $1 \beta$ abrogates negative inotropic effects in a model of chronic hyperleptinemia. Exp Biol Med (Maywood) 2011;236:1263-73.

75. Kandadi MR, Roe ND, Ren J. Autophagy inhibition rescues against leptin- induced cardiac contractile dysfunction. Curr Pharm Des 2014;20:675-83.

76. Orogo AM, Gustafsson ÅB. Cell death in the myocardium: my heart won't go on. IUBMB Life 2013;65:651-6.

77. Lee Y, Gustafsson AB. Role of apoptosis in cardiovascular disease. Apoptosis 2009; 14:536-48.

78. Zhang Y, Chen X, Gueydan C, Han J. Plasma membrane changes during programmed cell deaths. Cell Res 2018;28: 9-21.

79. Lee SD, Tzang BS, Kuo WW, Lin YM, Yang AL, Chen SH, et al. Cardiac fas receptor-dependent apoptotic pathway in obese Zucker rats. Obesity (Silver Spring) 2007;15:2407-15.

80. Lu MC, Tzang BS, Kuo WW, Wu FL, Chen YS, Tsai CH, et al. More activated cardiac mitochondrial-dependent apop- totic pathway in obese Zucker rats. Obesity (Silver Spring) 2007; 15:2634-42.

81. Hall ME, Maready MW, Hall JE, Stec DE. Rescue of cardiac leptin receptors in $\mathrm{db} / \mathrm{db}$ mice prevents myocardial triglyceride accumulation. Am J Physiol Endocrinol Metab 2014; 307:E316-25.

82. McGaffin KR, Witham WG, Yester KA, Romano LC, O’Doherty RM, McTiernan CF, et al. Cardiac-specific leptin receptor deletion exacerbates ischaemic heart failure in mice. Cardiovasc Res 2011;89:60-71.

83. Bernardi P, Di Lisa F. The mitochondrial permeability transition pore: molecular nature and role as a target in cardioprotection. J Mol Cell Cardiol 2015;78:100-6.

84. Dixon RA, Davidson SM, Wynne AM, Yellon DM, Smith CC. The cardioprotective actions of leptin are lost in the Zucker obese (fa/fa) rat. J Cardiovasc Pharmacol 2009;53: 311-7.

85. Smith CC, Dixon RA, Wynne AM, Theodorou L, Ong SG, Subrayan S, et al. Leptin-induced cardioprotection involves JAK/STAT signaling that may be linked to the mitochondrial permeability transition pore. Am J Physiol Heart Circ Physiol 2010;299:H1265-70.

86. Smith CC, Mocanu MM, Davidson SM, Wynne AM, Simpkin JC, Yellon DM. Leptin, the obesity-associated hormone, exhibits direct cardioprotective effects. Br J Pharmacol 2006; 149:5-13.

87. Eguchi M, Liu Y, Shin EJ, Sweeney G. Leptin protects H9c2 rat cardiomyocytes from $\mathrm{H} 2 \mathrm{O} 2$-induced apoptosis. FEBS J 2008;275:3136-44.

88. Shin EJ, Schram K, Zheng XL, Sweeney G. Leptin attenuates hypoxia/reoxygenation-induced activation of the intrinsic pathway of apoptosis in rat H9c2 cells. J Cell Physiol 2009; 221:490-7.

89. Engel D, Peshock R, Armstong RC, Sivasubramanian N, Mann DL. Cardiac myocyte apoptosis provokes adverse cardiac remodeling in transgenic mice with targeted TNF overexpression. Am J Physiol Heart Circ Physiol 2004;287:H1303-11.

90. Packer M. Is tumor necrosis factor an important neurohormonal mechanism in chronic heart failure? Circulation 1995; 92:1379-82. 
91. Micheau O, Tschopp J. Induction of TNF receptor I-mediated apoptosis via two sequential signaling complexes. Cell 2003;114:181-90.

92. Martinez-Abundis E, Rajapurohitam V, Haist JV, Gan XT, Karmazyn M. The obesity-related peptide leptin sensitizes cardiac mitochondria to calcium-induced permeability transition pore opening and apoptosis. PLoS One 2012;7:e41612.

93. Chen J, Mo H, Guo R, You Q, Huang R, Wu K. Inhibition of the leptin-induced activation of the p38 MAPK pathway contributes to the protective effects of naringin against high glucose-induced injury in $\mathrm{H} 9 \mathrm{c} 2$ cardiac cells. Int J Mol Med 2014;33:605-12.

94. Yu L, Zhao Y, Xu S, Jin C, Wang M, Fu G. Leptin confers protection against TNF- $\alpha$-induced apoptosis in rat cardiomyocytes. Biochem Biophys Res Commun 2014;455:126-32.

95. Haynes WG, Morgan DA, Walsh SA, Mark AL, Sivitz WI. Receptor-mediated regional sympathetic nerve activation by leptin. J Clin Invest 1997;100:270-8.

96. Dunbar JC, Hu Y, Lu H. Intracerebroventricular leptin increases lumbar and renal sympathetic nerve activity and blood pressure in normal rats. Diabetes 1997;46:2040-3.

97. Casto RM, VanNess JM, Overton JM. Effects of central leptin administration on blood pressure in normotensive rats. Neurosci Lett 1998;246:29-32.

98. Gardiner SM, Kemp PA, March JE, Bennett T. Regional haemodynamic effects of recombinant murine or human leptin in conscious rats. Br J Pharmacol 2000;130:805-10.

99. Bełtowski J, Jochem J, Wójcicka G, Zwirska-Korczala K. Influence of intravenously administered leptin on nitric oxide production, renal hemodynamics and renal function in the rat. Regul Pept 2004;120:59-67.

100. Beltowski J, Wójcicka G, Borkowska E. Human leptin stimulates systemic nitric oxide production in the rat. Obes Res 2002;10:939-46.

101. Lembo G, Vecchione C, Fratta L, Marino G, Trimarco V, d'Amati $G$, et al. Leptin induces direct vasodilation through distinct endothelial mechanisms. Diabetes 2000;49:293-7.

102. Winters B, Mo Z, Brooks-Asplund E, Kim S, Shoukas A, Li D, et al. Reduction of obesity, as induced by leptin, reverses endothelial dysfunction in obese (Lepob) mice. J Appl Physiol
(1985) 2000;89:2382-90.

103. Procopio C, Andreozzi F, Laratta E, Cassese A, Beguinot F, Arturi F, et al. Leptin-stimulated endothelial nitric-oxide synthase via an adenosine 5'-monophosphate-activated protein kinase/Akt signaling pathway is attenuated by interaction with C-reactive protein. Endocrinology 2009;150:3584-93.

104. Bełtowski J, Wójcicka G, Jamroz-Wiśniewska A, Borkowska E. Role of PI3K and PKB/Akt in acute natriuretic and NOmimetic effects of leptin. Regul Pept 2007;140:168-77.

105. Jamroz-Wiśniewska A, Gertler A, Solomon G, Wood ME, Whiteman M, Bełtowski J. Leptin-induced endothelium-dependent vasorelaxation of peripheral arteries in lean and obese rats: role of nitric oxide and hydrogen sulfide. PLoS One 2014;9:e86744.

106. Bełtowski J. Leptin and the regulation of endothelial function in physiological and pathological conditions. Clin Exp Pharmacol Physiol 2012;39:168-78.

107. Beltowski J. Leptin and atherosclerosis. Atherosclerosis 2006; 189:47-60.

108. Hoffmann A, Ebert T, Klöting N, Dokas J, Jeromin F, Jessnitzer B, et al. Leptin dose-dependently decreases atherosclerosis by attenuation of hypercholesterolemia and induction of adiponectin. Biochim Biophys Acta 2016;1862:113-20.

109. Shimomura I, Hammer RE, Ikemoto S, Brown MS, Goldstein JL. Leptin reverses insulin resistance and diabetes mellitus in mice with congenital lipodystrophy. Nature 1999; 401:73-6.

110. Liang CP, Tall AR. Transcriptional profiling reveals global defects in energy metabolism, lipoprotein, and bile acid synthesis and transport with reversal by leptin treatment in ob/ ob mouse liver. J Biol Chem 2001;276:49066-76.

111. Singh A, Wirtz M, Parker N, Hogan M, Strahler J, Michailidis $\mathrm{G}$, et al. Leptin-mediated changes in hepatic mitochondrial metabolism, structure, and protein levels. Proc Natl Acad Sci U S A 2009; 106:13100-5.

112. Targher G. Associations between liver histology and early carotid atherosclerosis in subjects with nonalcoholic fatty liver disease. Hepatology 2005;42:974-5.

113. Alkhouri N, Tamimi TA, Yerian L, Lopez R, Zein NN, Feldstein AE. The inflamed liver and atherosclerosis: a link between 
histologic severity of nonalcoholic fatty liver disease and increased cardiovascular risk. Dig Dis Sci 2010;55:2644-50.

114. Frühbeck G. Pivotal role of nitric oxide in the control of blood pressure after leptin administration. Diabetes 1999; 48:903-8.

115. Park HY, Kwon HM, Lim HJ, Hong BK, Lee JY, Park BE, et al. Potential role of leptin in angiogenesis: leptin induces endothelial cell proliferation and expression of matrix metalloproteinases in vivo and in vitro. Exp Mol Med 2001;33:95102.

116. Parhami F, Tintut Y, Ballard A, Fogelman AM, Demer LL. Leptin enhances the calcification of vascular cells: artery wall as a target of leptin. Circ Res 2001;88:954-60.

117. Gómez-Ambrosi J, Salvador J, Páramo JA, Orbe J, de Irala J, Diez-Caballero A, et al. Involvement of leptin in the association between percentage of body fat and cardiovascular risk factors. Clin Biochem 2002;35:315-20.

118. Esler M, Straznicky N, Eikelis N, Masuo K, Lambert G, Lambert E. Mechanisms of sympathetic activation in obesity-related hypertension. Hypertension 2006;48:787-96.
119. Muntzel MS, Al-Naimi OA, Barclay A, Ajasin D. Cafeteria diet increases fat mass and chronically elevates lumbar sympathetic nerve activity in rats. Hypertension 2012;60:1498502.

120. Simonds SE, Pryor JT, Ravussin E, Greenway FL, Dileone R, Allen AM, et al. Leptin mediates the increase in blood pressure associated with obesity. Cell 2014;159:1404-16.

121. Simonds SE, Cowley MA, Enriori PJ. Leptin increasing sympathetic nerve outflow in obesity: a cure for obesity or a potential contributor to metabolic syndrome? Adipocyte 2012; $1: 177-81$.

122. Lim K, Burke SL, Head GA. Obesity-related hypertension and the role of insulin and leptin in high-fat-fed rabbits. Hypertension 2013;61:628-34.

123. Rahmouni K, Morgan DA, Morgan GM, Mark AL, Haynes WG. Role of selective leptin resistance in diet-induced obesity hypertension. Diabetes 2005;54:2012-8.

124. Bell BB, Rahmouni K. Leptin as a mediator of obesity-induced hypertension. Curr Obes Rep 2016;5:397-404. 